\title{
研究定ノート
}

\section{私的病院の資金調達問題について： 資金需要推計と新たな資金調達スキームの提案}

河口 洋 行*

日本の私的病院における設備投資資金の調達は業種的な特性からみてあ，現在検討されている医 療保険制度改革への対応への必要性からみても, 病院経営というょりは医療政策上の重要な問題で ある。

しかし，現状では私的病院における長期資金の調達は，専ら銀行借入という単一チャンネルに頼っ ており，他業種に比して資金調達手段の多様化が行われていない。また，使用年数 30 年以上の病院 を全て建て替えるという仮定を扔いて，公私病院の病院建替の資金需要を粗く推計したところ，99 年までに最大で約 2 兆 6 千億円（年間設備投資の約 2 倍程度）の資金需要ギャップが存在している という結果となった。このような資金需給ギャップの原因は，私的病院と金融機関の間の情報伝達 が円滑に行われず，情報ギャップが大きいためと考える。

この情報ギャップを解消し, わが国医療インフラに必要不可欠な私的病院への資金供給を円滑化 するためには，私的病院側も情報開示を積極的に行うことを前提として，病院のための「格付機関」 および「格付を取得した病院への保証を行う機関」を創設することが必要と考える。また，これら の信用補完制度（格付機関・保証機関）は民間が主体となって整備することを提案する。

私的病院の資金調達手段の多様化については, 行政側として他業種とのイコールフィッティング に注意を払うとともに，民間が主体となってさまざまな資金調達手段の開発を行うことが期待され る。

キーワード 私的病院，資金調達，情報ギャップ，格付機関，信用保証機関

\section{1.はじめに}

米国で80年代にD R G / P P S方式が導入され た激動期に現場で病院経営を行った方々にイン夕 ビューをさせていただいた際に，彼らが強調した のは，病院経営を外部環境に適応させ効率化する ためには，「制度の変化を理解できる訓練された 職員」と「環境变化対応のための投資資金」の必 要性であった。つまり, 現場の創意工夫で対応で きる範囲を超えた環境変化に対しては新たな経営

* 国際医规福祉大学国際医省福祉總合研究所
を再構筑する「人」と「金」が調達できるかが， その経営体の命運を決するとの考え方である。

翻ってわが国を見てみると，私的病院を取り巻 く外部環境は80年代米国に近似しており，財政的 な制約から医療保険制度の支払方法の变更が検討 され，また病院や診療所等の医療サービス供給は ほぼ全国に行き亘るなかで，患者による病院選別 が激しさを增しているなど, 病院経営の一層の生 産効率化が要請されているところである。

特にわが国の私的病院は, 病床数が過剩となる 一方で，施設の設備平均年齢（ビンテージ）がか なり上昇していると思われる。今後の「抜本的な 医療制度改革」を進めるためにも，医療政策にお 
いて, 病院病床数を削減しながら必要な病院建替 を推進し, 将来的な経営環境変化に対応するため の設備投資資金の供給について方策を講じる必要 がある。

本稿では，以上のような問題意識に立ち，まず 医療政策における病院の設備投資の位置づけ (「2．医療政策における設備投資の位置づけ」) について筆者の意見を述べる。その後, 私的病院 の資金調達手段の現状之問題点（「3．病院の資 金調達手段の現状之問題点」) について概観し, 問題点の原因についての考察を行う（「4．資金 調達における問題点の原因について」)。最後に問 題点解決のための方策について, 新たな信用補完 制度の創設を含めて提案する（「5，問題解決の ための方策」。

このような病院の資金調達問題を政策論として 扱った論文は，驚くほど少ない。

わが国における病院の「設備投資の政策的重要 性」については，宮沢（2000）が医療福祉分野を 公共投資との比較において生産誘発の波及効果に 言及しているほかは，ほとんど議論されていない。

「病院の資金調達の実態」については，安川 （1997）が民間病院における外部資金調達の実態 として, 半数以上の病院が資金調達上の困難を訴 えていること，公的融資による外部資金調達が病 床規制以降も伸び続けていること，今後も民間病 院における公的資金需要は減退しない可能性が高 いこと等を把握している。また，田中（1993）で は病院経営の視点から資本コスト推計を行い, 1975年以降に開設された病院は，必要投資額を有 利子負債の増加によって賄なっていることを指摘 している。

「病院の資金調達における問題点」については, 規制という側面から八代 (2000) が, 組織論とし てみた営利企業の病院経営への参入禁止とは, 単 に株式発行による資金調達の手段を制約してい るにすぎないと主張している。同じょうに田中 （1993）でも医療法人に打ける配当禁止は, 長期
的には借入金より多くの有利性を併せ持つ株式や 債券などの発行という多様な資金調達手段を否定 しているため，借入金への依存を通じ，支払利子 の形で付加価値の外部流出をむたらしていると指 摘している。

このように病院の資金調達問題については，さ まざまなところで部分的に取り上げられているが, 本稿のように病院の資金調達問題を政策的な立場 加ら捉え, 分析し, 解決のための方策を具体的に 検討した論文は，新規性が強いと考える。

本稿での実証分析は, 筆者が2000年 4 月から 8 月までに行った「ヒアリング調査」結果を利用し ている。当該調查は, 合計 21 名の方に各 1 時間程 度で，資金調達環境や情報ギャップの内容等に関 して見解や具体的な数值等を頂いたものである。 21 名の内訳は, 病院経営者・事務長 6 名, 病院関 連団体役員 3 名, 医業経営コンサルタント・シン クタンク担当者 4 名, 監查法人 1 名, 格付機関 1 名, 金融機関営業担当者 2 名, 金融機関審查担当 者 2 名, 金融機関デリバティブ開発担当者 2 名で ある。それぞれの見解や主張を捕捉し利害関係に よるバイアスを考慮して実態を分析している。本 稿では特に断りがない限り，「ヒアリング調査」 とは当該調査を指す。

なお, 本稿での私的病院とは, 経営主体として は, 公益法人立, 医療法人立, 個人立, その他を 含み, 国立・公立（以下公立病院という）は含ま ない。本稿の分析においては，特に医療法人立病 院を中心に考えている。地域的には, (病床) 過 剩診療圈の大都市圏を想定しており, 病院を他業 種に比して業種特性の大きいと考えている。本稿 の目的は政策論であるが，政策の必要性を細かく 理解するため, 一部に経営論的な視点む入れて論 じる。

最後に, 本稿の内容は全て筆者の個人的見解で あり，所属する組織の見解ではないことを申し添 える。 
表 1 OECD諸国と比較した日本の医療インフラ

\begin{tabular}{|c|c|c|c|c|}
\hline & $\begin{array}{l}\text { In-patient care beds } \\
1000 \text { population }\end{array}$ & MRI unites & $\begin{array}{l}\text { Total health employment } \\
\text { / 1000population } \\
\text { (Practising physicians) }\end{array}$ & $\begin{array}{l}\text { Nursing home beds / } \\
1000 \text { population }\end{array}$ \\
\hline 日本 & 16.4 & 2.360 & $20.4(1.8)$ & 1.3 \\
\hline オランダ & 11.2 & 60 & $23.8(2.6)$ & i. ? \\
\hline ドイツ & 9.4 & 511 & $42.6 .(6.1)$ & 1.2 \\
\hline スウxーデン & 5.2 & 60 & 30.6 ( 6.1$)$ & 0.4 \\
\hline イギリス & 4.5 & 200 & $20.3(1.7)$ & 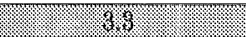 \\
\hline アメリカ & 4.0 & 4.200 & $(326,(2.1)$ & 2.0 \\
\hline
\end{tabular}

出所) OECD Health Data 99

注）数值は原則として 1997 年のもの（最新值を使用）

\section{2. 医療政策における設備投資の位置づけ}

\section{（1）病床数削減の政策と設備投資の役割}

a. 現在の医療サービス供給インフラの整備状況

わが国の病院数は現在 9,268 か所, 病床数は 1,647,086床となっており ${ }^{1)}, 1998$ 年 3 月31日現在 の医療計画 ${ }^{2}$ によれば，二次診療圏355加所のう ち過剩医療圈数は 160 となっており，必要病床数 約 147 万床に対して既存病床数は約 165 万床之, 既 に約18万床が過剩とされている。

国際比較のために，OECD Health Data '99を 見てみると，日本はベッド数と医療機器 (MRI) の数が多く, 医療従事者や介護施設（ナーシング ホーム）が少ない。ヨーロッパ諸国では医師や病 院職員等の人的資源が厚く，介護施設が充実して いる。一方で米国はMRI等の医療機器と人的資 源への投資が多い(表 1 )。

特に病院の観点から人口千人あたり病床数を比 較すると, 1997年時点で, 日本は16.4床/千人と 過去 3 年間を通じて一番多い。濃沼（2000）によ れば，OECD加盟国29か国は，1980～96年の17年 間で人口千人あたり病床数を平均 $27.4 \%$ 減少さ せている（年率約1.7\%)。わが国であ，今後病床 数からマンパワーや介護施設等への資源の配分が

\footnotetext{
1) 厚生省（2000）「医療施設実態調査」（平成12年 3 月 末概数)

2) 厚生省（1999）「厚生白書」（平成11年度版）
}

行われるのは必須であろう。

\section{b. 現在の政策の問題点と設備投資の役割}

(i ) 一律な規制の問題点

このため厚生省は「地域医療計画による新規病 床の規制」「病院施設近代化施設整備事業」等の 政策により病床数の抑制と病院建替の促進を企図 している。これらの政策は, 病床数には着目して いるむのの，その病床を所有する経営主体の生産 効率性についてはあまり注目していないという問 題点がある。

一般的にサービス供給を民間に依存するメリッ トは, 競争により生産効率的な経営主体に経営資 源が優先配分され，経済全体の効用を向上させる というあのである。

また投資決定理論においては；投資を行う経営 主体（通常は企業）は，投資による限界的な期待 収益が資本コストを上回る場合に行うこととなっ ている。このとき投資主体の投資機会曲線が個々 に異なるため，全ての経営主体が投資を行っても 同じ効果（効用の拡大）は得られない。

したがって，上記政策のように病床数に着目し て平等に規制や誘因を与えるのではなく，経営主 体に対して経済合理性の観点から一定基準を設け， その基準を満たした病院には誘因を与え満たせな い病院には規制を課す等の政策が望ましい。政策 金融において新規性の高い事業を審查の上担保条 件を緩和したり，家電製品に対して省エネ効果が 高い場合にある種の認証を与えるのは，よく知ら 
表 2 病院の倒産件数と統計上の減少数の乘離

\begin{tabular}{|c|r|r|r|r|r|r|r|r|r|r|c|}
\hline & \multicolumn{1}{|c|}{90} & 91 & 92 & 93 & 94 & 95 & 96 & 97 & 98 & 99 & 平均 \\
\hline 倒産件数(1) & 7 & 5 & 13 & 8 & 9 & 1 & 4 & 8 & 7 & 5 & 6.7 \\
\hline 減少数 (2) & - & 103 & 119 & 113 & 125 & 116 & 77 & 47 & 80 & $\mathrm{NA}$ & 97 \\
\hline (1)/(2) (\%) & - & 4.8 & 10.9 & 7.1 & 7.2 & 0.9 & 5.2 & 170 & 8.8 & - & 7.7 \\
\hline
\end{tabular}

出所）病院倒産件数 :「帝国データバンク」, 病院隇少数 :「医療施設調查」

れている手法である。

（ii）経済合理性による選別の実施について

このような考え方に対しては，病院のような公 共性が高く, 人の健康に関する事柄について, 経 済合理性を基準に判断してよいのか（例えば平等 に規制で行う）との考え方ああろう。しかし，既 にわが国は必要病床数を十分に確保している一方 で，現在の法的体系（自由開業制との整合性等） では政府が強制的に病院数をコントロールするこ とは困難と思われる。

同時に, 病院の統計上の減少数と病院倒産件数 を比較してみると大きく乘離（倒産は減少数の約 8\%）して抢り（表 2), 現実では, 経営悪化し た病院は，インフォーマルな形で経営権が経営状 態の良い病院へ移動している（例えば，経営破綻 病院のメインバンクが仲介し, 近隣病院に経営権 を委譲している等）と予想される。

つまり経済合理性を基準にした選別と資源の再 配分が既に行われていると推測できる。いずれに せよ, 病床削減が医療への資源配分上必要である ならば，経営主体の経済合理性（市場適正や生産 効率性）に着目した政策に転換する必要があろう。

\section{（2）病院の設備平均年齢（ビンテージ）と設備投 資について}

a. 政策における病院の設備投資の重要性について

（i）業種特性からみた投資需要

私的病院は，他業種に比して金融市場からの資 金調達に制限が課せられている（後述）一方で, その業種特性扝よび外部環境変化から，一般的な 財の生産に括ける能力増強や生産効率性向上の投
資の他にさまざまな資金需要が発生している。こ こでは主に(1)医療技術の進歩，(2)情報システム， (3)病院建替，の設備更新について述べる。むちろ ん別途病床からマンパワーへの経営資源の移行は 必要と考えている。

(1)医療技術の進歩

まず，医療技術の進歩に伴う投資を行う必要が ある。具体的には，新たな治療手法の開発や医療 機器が開発されると，国民が新たな技術の恩恵に 浴るように投資 (習熟時間む含めて) が必要とな る。地域の当該医療サービスの需給状況（地域で 投資に見合う需要があるのか，競合医療機関が既 に必要量を供給していないか）等から費用対効果 はきちんと検証する一方で, 継続的に投資するこ とが必要である。

(2)情報システム

病院における情報システムに対する投資の必要 性については，さまざまな点から指摘されており 論をまたないが，ここでは医療保険制度の抜本改 革等の外部環境変化に伴う, (a)「コスト管理」, (b)「プロセス管理」，について特に情報システム 投資が必要と考える。例えば，診療報酬における 支払単位の包括化が進められた場合, 収入が一定 になるため「コスト管理」が収益率を左右し， 「プロセス管理」が過小診療防止（過小診療・医 療事故が患者満足度に影響しひいては外来患者数 に影響するため）のため必要となる。

(3)病院建替

病院等の鉄筋コンクリート建物の法定償却年数 は39年であるが，わが国の病院においては，筧 （1996）にあるように，25年〜30年で建替えが行 
表 3 病院の建築年月別分布

\begin{tabular}{|c|c|c|c|c|c|}
\hline 使用年数 & 40 年超 & 30 年超 & 20 年超 & 10 年超 & 10 年未満 \\
\hline 建築年月 & $\mathrm{S} 34$ 年以前 & $\mathrm{S} 35 \sim 44$ 年 & $\mathrm{S} 45 \sim 54$ 年 & $\mathrm{S} 55 \sim \mathrm{H} \mathrm{1}$ 年 & $\mathrm{H} \mathrm{1} \sim 12$ 年 \\
\hline 割合 $(\%)$ & $1.8 \%$ & $11.8 \%$ & $24.5 \%$ & $35.3 \%$ & $26.7 \%$ \\
\hline
\end{tabular}

出菥) 平成 11 年 6 月医療経済実態調查（中央社会保険医潦協議会）

われている。これは, 患者サービスの多様化への 対応, 進歩する医療技術への対応や診療機能の拡 充, アメニティへの配慮等から, 一定期間で建替 を行う必要があるためと推測される。

（ii）現状の設備平均年齢（ビンテージ）の状況

病院建替の見地から平成 11 年 6 月医療経済実態 調査を見てみると, 全病院の約 $13.6 \%$ は既に建築 年月からみて使用年数が30年を超えている（表 3 ）。 先にも見たように筧（1996）によれば，病院建築 の寿命は25年から30年とされており, 特に今から 約 30 年前は戦後の経済成長の激しい時期であり, 建物の質もあまり高くないと指摘している。

\section{b. 現在の政策の問題点}

（i ）医療政策に抢ける病院の設備投資の重要性

一般的にサービスの生産においては, 現状の生 産要素 (資本と労働) を利用して可能なサービス 供給の量・質は一定の水準となる。このため, サー ビスの品質向上や量拡大のためには, 一定の投資 が必要となる。また, 冒頭の米国での事例にみら れるように, 大きな環境変化 (規制等) への対応 においても同様である。

政策的には，上記のような必要な設備投資資金 を確保しなければ，いくら医療保険制度改革によっ て誘因を強めてあ, 病院は環境変化に対応するこ とができない。その際には, 病床削減の必要性か ら，投資効果の高い経営主体を選別して投資を行 わせる必要がある。

（ii）設備投資年齢が生産性に及沽す影響と政策 的意味

特に病院建替の設備投資の問題は労働生産性の 向上にも影響を及ぼす。労働生産性は, 一般的に
付加価值労働生産性（=付加価値/従業員数 $\times$ 労 働時間）を指す場合が多く，この引上げのために は, 資本装備率（資本ストックメ稼働率／従業員 数 ×労働時間）を向上させることが多い。

私的病院では人員配置に関する規制により人件 費コスト（從業員数 $\times$ 労働時間）の削減余地に特 に乏しいため，稼働率の上昇資本ストックの増 加に頼らざるをえない。しかし，病院建替を引き 延ばすこと等により, 病院における設備の平均年 齢（ビンテージ）が上昇していると，その資本ス ・トックを増加させるための投資効果が阻害される 原因となる。表 3 にもみられるように，わが国の 病院ではビンテージが相当上昇している可能性が 高い。また，療養環境の改善等の患者二ーズや最 新医療機器の利用による医療提供方法の变化等に 対応するためにも，投資による設備更新（主に建 物) が重要と考える。

したがって, 必要な建替えが十分に行われ，ビ ンテージ上昇が過度にならないようするため, 政 策的に監視し，少なくとも必要な設備投資資金が 調達できるよう考虑していく必要があろう。

\section{3. 病院の資金調達手段の現状と問題点}

\section{（1）一般的な資金調達手段の概要 \\ a . 既往の資金調達スキームの整理}

\section{（i ）一般的な 3 つの資金調達手段}

私的病院に対する新たな資金調達スキームを検 討する前提として，まず一般的な資金調達手段全 体を概観する。一般的に企業は内部資金（主に内 部留保および減価償却費等) が充分ある場合には 外部資金の調達を要しない。しかし内部資金の蓄 
表 4 医療法人の盗金調達手段一覧表

\begin{tabular}{|l|l|l|}
\hline & \multicolumn{1}{|c|}{ 調達方法 } & \multicolumn{1}{c|}{ 特徽 } \\
\hline 借入金 & 金融機関から借入 & 多額の資金調達が可能 \\
\hline 増資 & 関係者や第三者から出資 & 配当禁止のため魅力小 \\
\hline 寄附金 & 関係者や第三者から募集 & 配当なしのため魅力小 \\
\hline 債券（縁故債） & 友の会会員から募集 & $\begin{array}{l}\text { 事務コスト大で魅力小 } \\
\text { 会員へのインセンティブが必要 }\end{array}$ \\
\hline リース & & リース物件価値の範囲内に限られる。 \\
\hline
\end{tabular}

(O2000 kawaguchi IRIHW.

積に時間がかかる場合や投資による収益率が資金 調達コストよりむ充分に高い場合には外部資金を 導入した方が有利であるため，企業は外部資金の 調達を行うこととなる。

外部資金の調達手段は多様であるが，貸借対照 表からみると 3 つに分割される。(1)エクイティ・ ファイナンス (資本面: 増資等), (2)デット・ファ イナンス（負債面：社債発行・銀行借入等), (3) アセット・ファイナンス（資産面：債権流動化・ 不動産証券化等）である。これらに内部留保等を 積み立てた内部資金が設備投資原資となる。企業 金融におけるFinancing Hierarchy理論によれば, 設備投資原資の優先順位としては，その資金調達 手段の資金調達コスト（投資家にとっては期待収

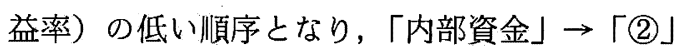

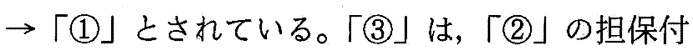
き貸出と同じポジションとなることが予想される。

また，資金の調達方法によってその資金の性格 あ異なり,一般的に株式は, 取引市場での值上が り益を享受できる一方で, 劣後債務 (企業が倒産 した場合に弁済順位が負債に比して劣後する）で あるためハイリスク・ハイリターンの資金とされ ている。銀行借入は, 資金提供側では貸出金利以 上のリターンは得られないことから，ローリスク・ ローリターンの資金とされている。

（ii）銀行借入から株式・社債を利用した資金調 達手段への移行の意味

また，直接金融手段において市場取引を行う場 合には制約条件が付加される点を，資金調達側
（私的病院）あ認識しておく必要がある。調達側 にとって直接金融は, 金利条件や資金調達量の点 で魅力的な方法である。しかし資金提供側（銀行 等）から見ると, 銀行借入は相対取引であるため, 極端にいえば両契約者が合意しておればいかなる 条件の取引あ是認される（公序に悖らないという 前提)。一方直接金融においては，一般的な公開 株式や公募社債は，不特定多数の投資家が参加す る市場取引への移行を意味しており, 発行者（私 的病院）に対して将来の財務状況・将来収益への 影響を及ぼす情報までも公開を求められることと なる。したがって発行者自体に一種の公共性が求 められ，市場の期待に沿えない場合には，他のよ り有利な投資案件に資金は急激に逃避する結果を 招く。これらの特性が，資金調達側となる現在の 私的病院の経営者マインドに合致するかについて は, 慎重な検討が必要となろう。

\section{（2）私的病院の現状における資金調達手段}

わが国の病院の資金調達手段は, 公立病院と私 的病院では大きく異なる。公立病院は, 設備投資 を民間金融機関だけでなく，公的財源から調達が 可能である。

私的病院は，株式での資金調達は事実上行うこ とができず，債券の調達む一般的でなく，専ら銀 行借入が主な外部からの資金調達の手段となって いる（表 4 ）。

銀行借入以外の資金調達手段としては, 資本面 では,「出資金」や「寄附金」の受け入れ，負債 
面では「社債発行」や「リースの利用」，また最 近は資産面で「診療報酬債権等の流動化」む利用 され始めている。しかし, 従来からの銀行借入に 取って代わるような，長期・大量の資金調達手段 にはなりえていないといえよう。

社会福祉 - 医療事業団の取引先企業統計 ${ }^{3)}$ で みてみると, 調達サイド（負債十資本）の合計 14,280円/床のうち，資本は3,242月（資本・ 負債の合計金額比で $22.7 \%$, 以下同)，負債は 11,038円（77.3\%）となっている。負債のうち短 期借入金は969円（6.8\%)，長期借入金は7,941円 （52.5\%）となっている。このように財務諸表か らみても，資金調達のかなりの部分を銀行からの 長期借入金に頼っていることが同われる。

\section{（3）私的病院の資金調達手段の問題点}

\section{a. 公的機関への依存度大}

（i ）融資全体への貢献度が高い

それでは，私的病院への直接の資金供給を行っ ている社会福祉・医療事業団 (以下事業団とする) の貢献度はどのくらいなのだろうか，またどのよ うな考え方に基づく資金供給を行っているのであ ろうか。

事業団の医療貸付事業の融資残高は99年度で約 1 兆 5 千億円となっており，城南信用金庫の融資 残高（1兆 7 千億円）之ほぼ同じ規模である。事 業団の病院・診療所向けの貸付金額は平成10年度 で2,768億円となっており，建築着工工事金額か らそのシェアを推定すると約 $31 \%$ とっている （社会福祉・医療事業団，2000）。したがって，事 業団は都銀等の民間金融機関に比して資金規模は 小さいむのの，一般的な企業向け融資を行う政策 金融機関（日本政策投資銀行，商工組合中央金庫， 中小企業金融公庫等) の合計の残高シェア（平成 12年 3 月末時点）が約 $5 \%$ であることと比較する と（フローベースとストックベースの違いはある

3) 社会福祉医療事業団 (1999)「病医院の経営分析指標」
が)，私的病院への資金供給では大きな役割を担っ ているといえよう。

（ii）生産効率性への視点が弱い

そもそも事業団のような財投機関（郵眝を原資 とした財投資金を政策的に直接投融資する機関）

は，民間金融機関が融資できない限界的な企業 （簡単にいえば，民間金融機関の審査基準ぎりぎ りで借入れできない企業）に対する資金供給を目 的としており，建前上は民間金融機関の補完的機 能を求められている。また, 貸付対象の選定に際 しては，民間金融機関よりあ公平性を（生産効率 性よりあ）重視せざるを得ない。

上記のように事業団は私的病院への資金供給に おいて大きな役割を果たしているといえるが，財 政投融資計画に基づいた資金供給となるため，予 算上の制約む大きく，建替えが必要な私的病院に 対して遍く資金を供給することは，過大な期待で あり現実的ではないといえよう。

（iii）財政投融資制度見直しの影響

併せて最近の財政投融資制度の改革により, 社 会福祉医療事業団の資金供給能力の減少が予想さ れる。財政投融資改革制度では，一括して大蔵省 理財局から借り入れていた財投資金量は減少し， それぞれの特殊法人等が自力で資金調達を行うこ ととなる。このとき，安定的でかつ充分な資金調 達が従来に比して困難になる可能性がある。

このため，私的病院への資金供給は民間の金融 機関を中心に考え，その利用に抢いて阻害要因が あるのであればそれを取り除き，資金供給が適切 に行われるような方策を考える必要がある。

\section{b. 単一チャンネルに依存}

\section{（i ）市場の失敗の発生}

私的病院の主な資金調達手段が銀行借入という 単一チャンネルであることは, 資金調達チャンネ ルが少ないということだけではなく，資金調達で きる資金の性格（例えばローリスク・ローリター ン資金のみ）が限られ，かつ当該資金調達チャン 
表 5 一般病院の支払利息比率の低下と収益率

\begin{tabular}{|c|c|c|c|c|c|}
\hline 20 & 4. & (1) & 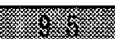 & 1. -3.6 & 7. 1. \\
\hline 支払利息比率（支払利息／総収益） & $2.8 \%$ & $2.4 \%$ & $2.0 \%$ & $1.7 \%$ & $1.5 \%$ \\
\hline 収益率（=1-〔総費用／総収益〕） & $1.2 \%$ & $2.6 \%$ & $3.3 \%$ & $4.2 \%$ & $3.1 \%$ \\
\hline
\end{tabular}

注）一般病院の平均值（97 年度の場合：サンプル数 675 , 平均病床数 176.1 床）

出所）「病医院の経営分析指標 1999」社会福祉医療事業団

ネルが機能しない場合（例えば，特定の業界に対 する審査能力にそしく新しい貸出を抑制する）に 他のチャネルを利用できない不利益を被ることと なる。例えば，後で述べるように，金融機関と私 的病院の間の情報ギャップにより信用割当のよう な状況になったとしても，他の資金調達手段がな ければ私的病院は市場から資金調達できず，財投 機関のような公的機関に頼ることとなる。

（ii）将来的な金融環境变化の影響

私的病院の資金調達手段の問題に対して，「経 営状況のよい病院は十分な調達ができている」・ 「資金調達問題は一部の経営悪化病院の問題であ る」との考え方むあるが，将来に亘っての安定的 な資金調達を考えると，そうは考えない。なぜな ら，現在の金融環境が変化した場合に現在よりも 資金調達が困難になる可能性が大きいからである。

例えば現在は歴史的な超低金利環境であるが, 将来金利が上昇した場合には，借入比率が大きい 私的病院経営は大きく悪化する可能性がある。93 年と 97 年の一般病院の支払利息比率を見てみると $1.3 \%(2.8 \% \Rightarrow 1.5 \%)$ と大幅に下降しており, 同時期の収益率上昇幅 $1.9 \%(1.2 \% \Rightarrow 3.1 \%)$ の $3 / 4$ を占めている(表 5 )。将来の金利上昇は 病院経営を圧迫し，その際に金融機関の貸出態度 が変化する可能性が高い。

また，規制等の変化によって病院経営の安定性 が損なわれ，それに対して銀行の貸出態度が変化 する可能性あある。

\footnotetext{
4)厚生省（1998）「医療経営実態調査」および「医療施 設実態調查」
}

以上のことから, 病院における現状の資金調達 チャンネルは, 単一チャンネルであるとの問題が あり, 特に現在の環境 (低金利・規制) 等が変化 した場合に，資金調達に関する問題が顕在化する 可能性が高い。

\section{c. 建替資金の需給ギャップが発生}

(i ) 病院の資金需要の推計

それではここで，民間金融機関からの資金供給 は本当に不足しているのかを検証し，その後なぜ 民間金融機関から私的病院への資金供給が充分に 行われていないのかについて考察したい。社会福 祉医療事業団（2000）では面積ベースから，私的 病院を全て建て替えると7.8兆円, 30年以上経過 した病院を全て建て替えるとすると 1.3 兆円が必 要としている。本稿では原則として病院数べース で, 建築単価の減少や 1 病院あたりの病床数の增 加を加味して推計を行っている。なお，前章では わが国の病床数は減少する万向であると述べたが, 本推計においては一旦全ての病院が建替えを行う との前提を置き, その後その妥当性について検証 したい。

\section{(1)借入金残高}

日本銀行の金融経済統計月報によれば，2000年 3 月末時点での医療業・公衆衛生業に対する銀行 貸出残高は約 12 兆円となっている（表 6 )。

この範囲の中で現在の病院の借入残高を粗く推 計する。平成 7 年 6 月医療経済実態調査（厚生省） にある平均長期借入金残高と短期借入金残に, 全 病院数をかけて算出した場合約 7 兆 2 千億円と推 計される。同様に医療法人立病院のみでは, 約 3 
表 6 医療保健衛生業への貸付残高及ひ新規設備投資 2000年 3 月末

\begin{tabular}{|r|r|r|r|r|r|l|r|}
\hline & 国内銀行勘定銀行信託勘定 & 海外店勘定 & 信用金庫 & \multicolumn{1}{|c|}{ その他 } & 社医事業団 & 合計 \\
\hline 貸 出 件 数 & 121,546 & 505 & 58 & 25,344 & 31,920 & N.A. & 179,373 \\
\hline 融 資 残 高 & 87,942 & 513 & 239 & 11,690 & 3,605 & 14,878 & 118,867 \\
\hline うち設備投資 & 61,021 & 402 & 136 & 8,083 & 2,787 & N.A. & 72,429 \\
\hline 新規設 備投資 & 12,976 & 20 & 0 & 1,832 & 752 & N.A. & 15,580 \\
\hline
\end{tabular}

注1）医療・保健衛生は標準産業分類上の中分類医療業と保健衛生業を合わせたすの

注2）医業は病院，一般診療所，歯科診療所，老人保健施設，あ九ま針所等を含む

注3）保健衛生業は保健所，検診所を含む

注4）国内銀行は, 都市銀行, 地方銀行, 第二地銀, 信託銀行, 長期信用銀行の合計

注5）その他は大蔵省管轄の政府系金融機関の合計

注6）新規設備投資は2000年 $1 \sim 3$ 月の実績を 4 倍して年間換算している

出所）金融経済統計月報（日本銀行）, 社会福祉医療事業団パンフレット

\section{表 7 病院の資金輀要推計結果の概要}

\begin{tabular}{|c|c|c|c|c|}
\hline & 借入残高 & 新規設備投資 & \multirow{2}{*}{\multicolumn{2}{|c|}{$\begin{array}{l}\text { 建替資金需要（中価格ケース） } \\
(-9 \text { 年迄 } \quad 04 \text { 年迄 })\end{array}$}} \\
\hline & （ストック分） & (フロー分) & & \\
\hline 医療・公衆衛生業 & 12.0 兆円 & 2.0 兆円 & N. A. & N. A. \\
\hline 病院＋唁療所 & N. A. & 1.7 兆円 & N. A. & N. A. \\
\hline $\begin{array}{l}\text { 病院 } \\
\text { (うち医法立等) }\end{array}$ & $\begin{array}{l}\text { 7.2 兆円 } \\
\text { (3.2 兆円) }\end{array}$ & $\begin{array}{l}1.2 \text { 兆円 } \\
(0.8 \text { 兆出) }\end{array}$ & $\begin{array}{l}2.6 \text { 兆円 } \\
(1.4 \text { 兆円 }) \\
\end{array}$ & $\begin{array}{l}1.9 \text { 兆円 } \\
\text { (1.0 兆円) }\end{array}$ \\
\hline
\end{tabular}

(C2000 kawaguchi IRIHW.

注 1）新規設備投資額での医法立等は医法・公的・その他を含む。

注 2 ) 建替資金需要は，中価格ケース（建築単価 70 万円/坪）として推計している。

注 3 ）この他に病院の関連する資金需要としては，以下の福祉事業関連事業が想定される。

福祉事業関連資金需要推計の概要

\begin{tabular}{|c|c|c|}
\hline 福祉関連事業 & 年間投資資金 & 民間資金部分 \\
\hline 社会福祉施設 & 約 6 千億円〜 & 施設あたり 1千万〜 2 億円 \\
\hline 在宅介諾サービス & 約数十億円〜 & ほぼ全額 \\
\hline $\begin{array}{l}\text { 有料老人ホーム等 } \\
\text { (有料老人ホーム類似施設 }\end{array}$ & 約 1 千億円〜 & ほぼ全額 \\
\hline
\end{tabular}

(O2000 kawaguchi IRIHW.

注）有料老人類似施設のうち，ケア付き住宅部分は今後大幅な增加を見込む。

住宅供給公社で 2005 年までに 10 万戸を整㒉予定（日経新開 00.06.22）。

兆 2 千億円と推計される（表 7 ）。

(2)新規設備投資資金

日本銀行の金融経済統計月報によれば，現在の 年度ごとの設備投資額は, 医療業・公衆衛生業で 約 2 兆円（年間設備投資額を借入金比率約 8 割で 割り戻して産出）となっている。この範囲の中で 毎年の病院の新規設備投資額を粗く推計する。平 成10年度建築統計年報（建設省）の工事着工予定 額より約 1 兆 2 千億円と推計される。特に医療法 人病院等は, 約 8 千億円と推計される（表 8 ）。

(3)建替用設備投資資金

今後病院建替に必要となる設備投資資金を推計
する。使用後30年以上経過した病院を建替が必要 之仮定する。平成 7 年医療経済実態調査（厚生省） にある使用年数 30 年を超える病院数の合計に 1 病 院あたり平均1,428百万円（当該調查対象病院平 均病床数 170 床 $\times$ 建築単価 1 㦿あたり 8.4 百万円 〔坪建築単価70万円 $\times 1$ 床あたり面積 $40 \mathrm{~m}^{2}$ 〕 をか けて算出すると，99年までに投資が必要であった 資金額は約 2 兆 6 千億円と推計される。建築単価 については, 建設会社・病院経営者等にヒアリン

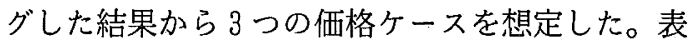
2 にはそのうちの中価格ケースでの推計結果を記 載している。ここでは, 使用年数 30 年を超える病 
表 8 病院・診療所 工事予定額

\begin{tabular}{|c|c|c|c|c|c|c|c|}
\hline & 合計 & 国 & 都道府県 & 市町村 & 会社 & 医療法人筀 & 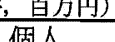 \\
\hline 建築数 & 3,914 & 90 & 42 & 170 & 305 & 1,542 & 1,765 \\
\hline うち新築 & 2,093 & - & - & - & - & - & - \\
\hline うち増築 & 1,793 & - & - & - & - & - & - \\
\hline うち改築 & 28 & $\begin{array}{ll}- \\
-\end{array}$ & - & - & - & - & - \\
\hline 工事予定額 & $1,172,052$ & 120,403 & 62,248 & 86,132 & 79,013 & 711,366 & 112,890 \\
\hline うち新築 & 637,805 & - & - & - & - & - & - \\
\hline うち増築 & 530,091 & - & - & - & - & - & - \\
\hline うち改築 & 4,156 & - & - & - & - & - & - \\
\hline
\end{tabular}

注1）出所は，建築統計年報（平成10年度版）

注2）建築基準法に基づく届出義務のある休面積10平方メートル超の建築物を全て含む（悉皆調查）

注3）工事予定額は着工ベースでの集計となっており, 建築工事の進渉・予定変更が計上されていない

注4）建築物の使途において病院・診療所を集計しており，病院診療所の内訳は不明

注5）医療法人等とは，会社でない法人（医療法人・社会福祉法人等）および法人でない団体を指す

注6）新築とは，既存の建築物のない新たな敷地に建築物を建てる工事をいう

增築とは，既存の建築物のある敷地内において，床面積の合計汃增加する工事をいう

改築とは，建築物の全部または一部を除去し，用途等の著しく異ならない建築物を建てる工事をいう

注7）病院経営実態調查の設備投資額に占める建築費割合で工事予定額を割り戻して設備投資額を推計

院は建替えを行うとの仮定に基づいているため， 病院の統廃合による建替しないケースについては 考慮していない点に注意が必要である。

併せて今後 5 年間 $(00$ 年 04 年) について粗く 推計試算すると, 1 兆 9 千億円の建替資金需要が 発生すると推計される（表 9 )。

（ii）病床削減政策の影響について

上記推計は，現在の病院が全て建替を行うとい う仮定を置いているが，現実には，病院数は医療 施設調查によれば，毎年約 $1 \%$ ずつ減少している。 また，欧米諸国のように病院施設からマンパワー や介護施設に資源シフトが起きると考えると，全 ての病院を建替るとの仮定はやや大胆とも思われ る。

念のため他のOECD諸国並みに千人あたり病床 数を削減すると仮定し, 現在の病院数をどのくら い削減する必要があるかを単純に算出し, 現在建 替が必要となっている病院数と比較した。

例えば，表 1 にあるオランダは千人あたり病床 数が11.3とわが国に比較して $30.2 \%$ 少ない。同じ 割合でわが国の病院数が何十年かかけて減少して いくと仮定すると，日本の病院で換算して 2,847
病院を削減することとなる。この数值は，99年ま での建替えが必要な病院数よりも多く（したがっ て建替必要なし), 00 04年の建替病院数 3,188 病 院のうち2,193病院を建て替えることとなる。こ の結果を設備投資金額に置き直すと99年までは 建て替えないとして 0 兆円，00～04年まででは 1.31兆円が必要との結果となる。

もちろん，上記試算はOECDの病床数の算定方 法（日本の場合は慢性期病床数が多くカウントさ れていると予想される)，を厳密に検討していな いという意味で乱暴なあのである。また，上記削 減病院数 $(2,847$ 病院）は, 現在のわが国でいえ ば「医療法人立病院および個人立病院」以外の全 ての病院数に匹敵する水準であり，この数值は現 実的ではない。事実現在のわが国の病院減少ペー スは年率 $1 \%$ 程度（OECD平均では過去17年間で 1.7\%ずつ削減）であり，オランダ並みになるに は, 30年（OECDベースで18年）が必要であり， 今次推計值における全ての病院が建替えを行うと の仮定は, 今後 5 年程度では一定の意味をむつと 考えられる。 
表 9 病院建替資金の推計

\begin{tabular}{|c|c|c|c|c|c|c|c|c|}
\hline 建築年月 & 1944以前 & $45 \sim 49$ & $50 \sim 54$ & $55 \sim 59$ & $60 \sim 64$ & $65 \sim 69$ & - & $70 \sim 74$ \\
\hline 使用年数 & 55 年以上 & $50 \sim 55$ & $45 \sim 50$ & $40 \sim 45$ & $35 \sim 40$ & $30 \sim 35$ & - & $25 \sim 30$ \\
\hline 該当サンプル数 & 5 & 0 & 11 & 20 & 53 & 144 & - & 168 \\
\hline 割合（\%) & $0.4 \%$ & $0.0 \%$ & $0.9 \%$ & $1.7 \%$ & $4.5 \%$ & $12.2 \%$ & - & $14.2 \%$ \\
\hline 予想病院数 & 40 & 0 & 87 & 159 & 421 & 1,145 & - & 1,336 \\
\hline 設備資金（億円) & 568 & 0 & 1,249 & 2,271 & 6,017 & 16,348 & $\mathbf{2 6 , 4 5 2}$ & $\mathbf{1 9 , 0 7 3}$ \\
\hline & & & & & & & 1999 ま゙ & $2000 \sim 04$ \\
\hline
\end{tabular}

注1）建築年月別の病院分布は「医療経営実態調查（平成 7 年 6 月）」, 病院数は「病院施設調查（平成 8 年)」 ょり引用

注2）調查サンプルの病院総数（一般病院十精神病院）は層化無作為抽出した1,187病院（カバー率約 $12 \%$ )

注3） 97年度の建築年月別の予想病院数は, 上記医療経営実態調査の建築年月分布之同様であると仮定して推計

注4）所要設借資金は使用年数 30 年以上の病院は全て建て替えると仮定して推計

注5） 1 病院あたりの建替資金は1,498百万円（平均病床数170床 $\times 1$ 床あたり建築単価8.4百万円）として推計

注6）1999年までに全て建て替えた場合の所要建替資金は，約 2 兆 6 千億円と推計

注7） 2000 年より 5 年間で発生する新たな建替資金は 1 兆 9 千億円と予想

（iii）建替用設備投資資金の不足感

上記のとおり，病院の建替資金需要は，廃院や 統合を考慮していないことああるが，99年までで 最大 2 兆 6 千億円と，現在の年間投資額の 2 倍以 上の資金需要が存在している状態にあることが同 われる（但しこの資金は内部留保や減価償却費に よって部分的には賄われる)。厚生省の実施した 病院経営緊急状況調查（平成 5 年）のアンケート 結果によると, 病院建替の阻害要因としては「資 金調達ができないため」との回答が, 全体の過半 を占めており，事業継承・建替用地確保の問題も あるあのの，資金調達が主な原因となっていると いえる ${ }^{5)}$ 。但し, 残念ながらこのアンケート調査 では，資金調達できない原因については触れられ ていない。

したがって，99年までの資金需要の超過部分 （最大 2 兆 6 千億円）と00 04年に発生すると予 想される資金需要分（最大 1 兆 5 千億円）を併せ て，今後 5 年間で投資していくと仮定すると，年 間最大 9 千億円の設備資金が追加で必要になると 考えられる。この部分の資金調達について特に懸 念されるところである。

以上のように病院の資金調達においては，わが

5) 厚生省 (1993)「病院経営緊急状況調查」
国の医療インフラを適正に維持していくのに必要 な資金が十分に調達できていないと推測できる。

次にわが国私的病院の資金調達における需要と 供給のギャップを解消する方策について検討する ため，問題の原因を分析する。

\section{4. 資金調達における問題点の原因に ついて}

\section{（1）事実上単一チャンネルによる資金調達}

a. 制度上の制約とその根拠

\section{（i ）事実上銀行借入が長期資金調達手段}

「病医院のための資金調達マニュアル」（日経 $\mathrm{BP}$ 社）によれば，外部資金調達における增資等 については多額の調達が困難で, 寄付金について は, 調達手数がかかりすぎ，債券については事実 上縁故債（特定少数の縁故者に発行, 出資法上の 届け出を行えば発行条件などの制限なし）しかな く,やはり金額の割に調達手数がかかるとしてい る。したがって現実的には銀行借入れが特に長期 資金については唯一の調達手段となっている。こ れは医療法人制度が中間法人という暧昧な位置づ けになっているため, 他業種のように株式会社を 前提とした制度が利用しにくいためであある。 
（ii）外部資金調達の制限の意味

また，八代（2000）では，同書の主張ではない が，病院債禁止の理由における理由として，「銀 行借入は認可業種である銀行との相対取引である が，株式の発行は不特定多数之の金融取引である ため，暴力団等の好ましからざる第三者の影響力 が及ぶ危険性が指摘されており，これが株式と同 じ直接金融の手段である病院債の発行禁止の論拠 と言われている」と闌外に記載されている。しか し, 現実には医療法人といえども企業間信用（取 引に伴う企業同士の信用供与：例えば手形や企業 間の貸付）は行っており，他の組織からのさまざ まなルートでの資金供給は可能である。仮に上記 主張を是とするならば，株式（商法にて経営参加 権が担保されている）までの限定については肯定 される面もあるが, 社債等についてまで外部の影 響を懸念して制約することについては合理的な根 拠が見あたらない。

田中（1993）によれば，「長期的には，借入金 より多くの有利性を併せ持つ株式や債券などの発 行という多様な資金調達手段を否定しているため, 借入金への依存を通じ，支払利子のかたちで付加 価值の外部流出をあたらしている」との指摘がな されている。

\section{（2）金融機関と私的病院間での情報ギャップ}

\section{a 、リスクプレミアムの認識の違い}

（i）投資家と私的病院のリスクプレミアムにお ける認識の違い

一般的に投資家は，「期待収益」「リスク」, 「流動性」，「税制上の利益」の 4 つを考慮して投 資を決定する。ここでは市場を完全であることを 前提とし，「流動性」と「税制上の利益」を無視 し，「期待収益」と「リスク」によって投資を決 定すると考える。

これまで実質的に銀行借入以外の手段（例えば 株式や社債による直接金融）が行えなかったのは, 資金提供者が望む期待収益率と私的病院が許容す
る資金調達コストが一致しなかったためとの主張 がある。例えば, 私的病院が無担保公募社債を発 行できたとしても，投資家が期待収益率を $7 \%$ と した時，私的病院の当該資金投下による収益率が $5 \%$ であれば，私的病院はその資金を調達して運 用してあ逆ざやとなってしまう。この場合には通 常資金調達は行われない。

また，他業種との比較で考えると「プライムレー ト」と「リスクプレミアム」の関係で説明するこ とができる。投資家はほとんど信用リスクのない 投資対象については「資金の利用に対する便益の 対価としての利子率」を要求する。これをプライ ムレートという。しかし，業種比較において信用 リスクが高い場合には，それに見合ったリスクプ レミアムを要求する。したがって私的病院の資金 調達コストは以下の式のようになる。 資金調達コスト $(\mathrm{r})=$ ）プライムレート $(\mathrm{P})+$ リスクプレミアム（R)

「ヒアリング調査」によれば，投資家（資金供 給者）の考えるリスクプレミアム（Rsとする） 之私的病院（資金調達者）の考えるリスクプレミ アム（Rdとする）部分についての認識のズレ （Rs > Rd）が原因となっていると推測される。

それでは私的病院の事業は, 他業種に比して 「リスク」が高い業種であろうか。リスクプレミ アムに関連する要素として「黒字割合」と「収益 率」をみてみたい。

（ii）公私病院による格差が大きい黒字割合 病院の黒字割合については，個別の私的病院の 財務諸表が公表されていないことから 3 種類のア ンケート調査をチェックしてみた。ここで特徵的 なのは, 公的病院と私的病院で黒字割合が大きく 異なる点である。私的病院では約 6〜 7 割が黒字 であり, 公的病院では $2 \sim 3$ 割が黒字と対照的で ある。したがって, 公的病院の割合が大きいアン ケート調查では黒字割合が低くなり，私的病院の 黒字割合が投資家から実際より屯低く認識される 可能性が高い。 


\section{(iii）高い収益率}

私的病院の収益率について，アンケート調查に 比してバイアスの入りにくい公認会計士取引先調 査で，かつ他業種との比較が可能な「TKC経営 指標」からみてみる。TKC経営指標（99年度） より黒字企業平均で比較すると, 医療業の収益性 は経常利益べースでみても7.3\%（うち一般病院 は5.6\%）とサービス業平均 $4.3 \%$ に比して高い収 益を誇っている。比較的社債等によって資金調達 をよく行う製造業3.6\%，電気ガス水道業3.2\%に 比しても, 収益の安定性を考慮に入れなければ, 優れているといえよう（私的病院は, 銀行借入の 比率が大きいため貸出金利低下の好影響が大きい ことにも注意が必要)。もちろん，資金調達にお いては，収益率の絶対水準が高いことに加えてそ の変動率（安定性）も重要である。

\section{b. 情報ギャップの及ぼす影響}

（i）資本市場における情報ギャップの影響

リスクプレミアムに関連する黒字比率や収益率 が比較的高いにも関わらず，「ヒアリング調查」 によれば，投資家の想定するリスクプレミアムが 私的病院（資金調達者側）が想定している水準よ りも高く想定されている傾向がみられるのはなぜ であろうか。あちろんここでの問題は認識のズレ の大きさであり, よ゙ちらのリスクプレミアムが適 正であるかではない。筆者は両者の情報ギャップ が大きくなっているせいではないかと考える。

資本市場において情報の非対称性が存在する場 合には，「逆選択」や「信用割当」の状態になる とされている。これらが起こると「リスクの低い 者」は，借入金利が割高となるため市場から退出 し，「リスクの高い者」は，高い金利を払う意志 をむっていてあ借入ができなくなる。

（ii）逆選択

「逆選択」は，私的病院と金融機関があつ私的 病院に関する情報に偏りがある場合に発生すると 考えられる。金融機関は個別の私的病院の信用リ
スクが充分に判定できない場合には，やむを得ず 一律の利子率の水準を適用することとなる。一方 で私立病院側は自身の信用リスクを充分に認識し ているとする。この場合, 信用リスクの低い私的 病院にとっては, 他の信用リスクの高い病院と同 じ，割高な資金調達コストを要求されることとな る。この時，信用リスクの低い私的病院が他の資 金調達手段を持っているか，資金調達を延期する ことが可能であれば，当該資本市場から退出する こととなる。しかし，他の有力な資金調達手段を 持たない私的病院では,このことは資金調達が大 きく阻害されることを意味する。

(iii）信用割当

一方で, 一律の利子率は, 信用リスクの高い私 的病院にとっては, 割安の金利水準となる。しか し「信用割当」が起こると, この場合も借入が困 難となる。

「信用割当」とは，ある資金調達者が，他の資 金調達者より高い金利を支払ってよいと考えてい るとしてあ，資金供給者が貸付を行わない状態を 示す。この時, 資金供給者（金融機関）は, 資金 調達者（私的病院）の期待収益率は一定水準であ ると考え，加資金調達者の行う経営の全てをモ ニターできないと認識している。このため, 資金 供給者が資金調達者への貸出金利を引き上げると, かえって資金調達者をリスクの大きい経営（ハイ リスクハイリターンの投資やレピュテーションリ スクを考えない収益追求）に駆り立てることとな り, 結果として資金調達者（私的病院）の期待収 益率が低下することとなる。そのため市場金利や 市場金利より高い金利水準でも貸出を行わなくなっ てしまうというものである。

「逆選択」や「信用割当」の状態が全国で一律 に起きているとは考えにくいが，先の資金需給推 計で見たような大きな資金需給ギャップが起きて いることから，それぞれ個別状況の異なる金融機 関と私的病院の間でかなりの頻度で発生している と推測される。もちろん, 資金供給と調達の問題 
に関しては，私的病院と金融機関で見解が相違す ることは避けられず，金融ビックバンによって金 融行政・金融機関の行動が大きく变わりつつある なかで資金調達者（私的病院等）の認識が旧来の ままであることも問題であるが，一方で収益率や 信用リスクの点で問題がないと思われる私的病院 に対して，資金供給が充分になされない例が多い のも事実であろう。

（iv）業種別の情報の偏り之経営格差拡大の影響

また，業種ごとに入手可能な情報量に多寊の差 がある場合には，金融機関としてはより情報を多 く入手できる業種に資金配分を厚くする誘因が働 くため, 情報の入手が他業種と比較して困難と思 われる私的病院には，他業種に劣後した資金配分 を行うことが想定できる。これは病院経営に関す る信頼性の高いデータベースが少なく，客観的な 指標との比較が充分に行われない場合に発生する 可能性が高い。

併せて，これまで以上に病院の経営格差が大き くなってきたことむ, 経営情報の伝達がうまくい かない状態では好ましくない。このような要因に よっても私的病院全体の資金アベイラビリティ （資金調達の容易さの度合い）が低下する可能性 があると考える。

以上のことは，銀行借入以外に有力な資金調達 手段を持たない私的病院にとっては深刻な問題で あり（一般企業であれば株式・社債市場へのアク セスが別途可能), 一定数の病院が社会インフラ として必要不可欠なことからみてあ，業界全体と しての情報ギャップ解消手段を講ずる必要がある と考える。そのためにあ，次に情報ギャップの内 容を見てみる。

\section{c． 金融機関との情報ギャップの内容}

（i ）主な審査項目と情報ギャップの大きさ

銀行が貸出に際してチェックする「(1)審查項目」 から具体的な情報ギャップの内容とその大きさを みていきたい。大まかに, (a)医療サービスの品質, (b)規制を含めた業種動向，(c)地域の医療サービス 市場分析, (d)経営能力評価, (e)投資妥当性, (f)収 益力・効率性，(g)財務安定性，(h)担保・保証人の 8 項目について考える。当該項目について「ヒア リング調查」や業種特性から情報ギャップを考え ると,ギャップが大きいのは(a)から(c)，小さいの は(f)から(h)，その中間が(d)から(e)と考えられる。 またこの他に，外部環境に関連して「(2)私的病院 への先入観」,「(3)財務データの信頼性とチェック 機能」が弱い点が情報ギャップの要因になってい ると思われる。それでは次に外部環境からくる2 点 (2)，(3)）について具体的内容を見てみたい。 （ii）私的病院への先入観

病院の経営状況に対する赤字のイメージについ ては,「公私病院連盟病院経営実態調査」等では 病院の赤字割合が相当高いため, 不採算業種であ るとのイメージで受け取られやすいとの結果が 「ヒアリング調查」から推定できる。また，医療 法人制度における，非営利原則についても，営利 を目的とする融資ビジネスの対象としては馴染み にくいとのイメージで受け取られやすい。 （iii）財務データの信頼性, チェック機能 一般的に他業種に比して財務諸表の整備状況が 劣っており，基本的な財務デー夕に対する信頼性 がそしい。診療と経営が分離していない（例えば 診療を優先して経営を劣後させる等）点でも財務 デー夕作成に必要な経営資源を充分に投入するか という不安あある。また，原則として財務諸表が 公開されていないので, 標準的な財務データベー スに乏しく，同業他社との財務データ比較が行い にくい。金融機関は通常自分の取引先財務データ を蓄積して利用するが，業種特性が大きい反面， 事例が多くないため，デー夕数が不足しがちであ る。

\section{d．病院側の情報公開へのスタンス}

、一方私的病院側として屯，資金調達のためには, 一層の情報公開が求められる。現在の医療法人制 
度によれば, 決算後 2 か月以内に決算書類（病院 会計原則に基づく「貸借対照表」「損益計算書」 「利益処分計画書」「付属明細書」）を作成し，都 道府県知事に届け出るとともに, 自ら備置するこ ととなっている。

これに対して，公開企業（株式を取引所に上場 している企業) では，決算書類の作成に際しては 会計監查人の監査を受け, 半期ごとに有価証券報 告書を提出し，また証券取引法における重要事実 （重要な資産処分や事業提携等一定の基準を満た す事項）が発生した場合にはすぐに情報開示を行 うなど，厳しい情報公開が義務づけられている。 併せて一部の企業では，市場から評価されるため に, IR (Investor Relationship) 活動として, 法令等に定められていない情報まであ積極的に株 主等に公開してきている。これらに比して病院側 の情報公開へのスタンスは非常に弱いといわざる を得ない。

これは, 病院の持ち分等が私的財産として認識 され，その内容を隠したいという誘因が働きやす く, かつ上記情報公開のルールが比較的緩やかで あることが原因であると推測している。今後は資 金調達において，情報開示をすればするほど金利 等の調達条件が有利になるような誘因が働くよう な形となることが重要であると考える。

\section{5. 問題解決のための方策}

\section{（1）病院の積極的な情報公開}

\section{a. 情報公開の基盤整備之私的病院の経営方針}

（i ）情報公開のための基盤整備

外部からの資金調達を行う場合に，情報公開の 度合いが進んでいる方が，投資家にとっては，よ り完全な情報が得られるという点で有利である。 また，金融機関もさまざまな業種に資金供給する 場合，より情報の多い業種により多くの資金を割 り当てる可能性む大きい。
に比して劣後しないような情報開示制度を整備す るか, 少なくとあ私的病院の自主的な情報開示を 妨げないよう医療制度に注意を払う必要があろう。 特に, 私的病院の自主的な取り組みとしては, 財 務諸表の透明性の向上と長期的な事業計画や設備 投資・資金調達の計画を作成することが望まれる。 （ii）情報公開を志向しない私的病院の資金調達

一方, 個人的な考えや組織の方針として情報公 開を好まない場合には，内部での資金調達を行い その範囲での事業展開を行うことを選択すべきで ある。実際一般企業において屯同族による経営を 方針とし，外部資金調達を抑制している場合は多 い。但し，私的病院経営においては，別途「医療 サービスの公共性」と「公的保険の給付対象」で あることについても留意が必要であろう。

\section{（2）新たな資金調達テャンネルの検討}

\section{a. 現状における直接金融の利用可能性について}

現状では，東京都の中小企業向け社債市場の検 討状況をみてもわかるように，わが国での直接金 融手法の育成にはさまざまな基盤整備等が必要之 思料される。また直接金融を利用するためには, (1)厚い投資家層，(2)投資家の判断を助ける信用補 完制度，(3投資銀行等の経験豊かなエキスパート 等が必要であるが，現在は十分整備されていない。 したがって，当面は直接金融手段の利用は困難で ある。

むしろ，現実的には，現在医療生協等を中心に 行われている地域住民を「友の会」等に組織し， 病院経営への参加を求めかつ個別の借入契約によ り資金を調達（証書として債券を発行する）する スキームを改良していくことが現実的と思われる。 当該スキームは地域に根ざした私的病院では，特 に有効であると考える。 


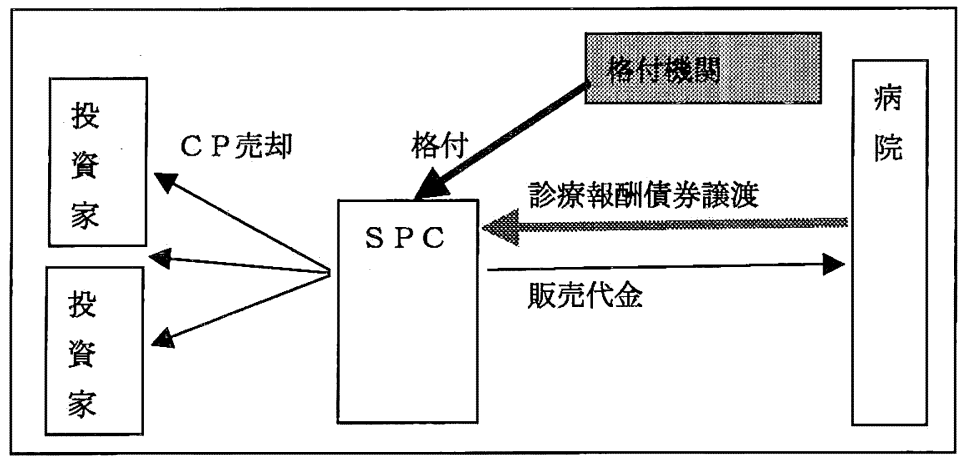

図 1 診療報酬渍権流動化スキーム

b . アセットファイナンスを利用した新たなスキーム

（i ）診療報酬債権流動化スキームの改良一優良 資産の利用

一般的な資産の流動化は，その資産の価値とそ こから生み出される収益を背景にして，比較的低 コストで資金調達をするものである。したがって， 収入が診療報酬という優良な債権である私的病院 に向いている資金調達方法である。

しかし現在の診療報酬債権流動化スキームの問 題点は，ほとんど貸し倒れのない診療報酬債権を 裏付けにしながら, 結局, 高額な保証料や事務手 数料を負担するなど高コストであることで, 審査 支払機関の協力による事務コスト低減や厚生省の スタンス変更による利用促進等により更なるスキー ム改善が望まれる（図 1)。

（ii）不動産流動化スキームの検討

不動産流動化スキームは私的病院の保有する土 地建物の価値とそこから生み出される収益を背景 として資金調達を行うあのである（図 2)。従来 私的病院の土地建物については担保評価において 収益還元法よりも取引事例比較法により評価され ると不利（公的性格から売却・転用が困難）であっ たが，当該スキームはこの点を改善し私的病院が 保有する土地建物の生み出すキャッシュフローに 注目する。本質的にホテルやショッピングモール で既に行われている不動産流動化と同じであるが, 私的病院の経営主体が株式会社ではなく医療法人
であることから，オペレーターの選定，エクイティ （株式相当）部分の資金供給や資金返済方法（通 常 5 年後)について，業種特性（特に非営利原則 との親和性）を踏まえた改良が今後必要である。 また，スキーム組成の際には，工場財団を範とし た病院の土地・建物・機器等を一体として評価す る病院財団等の評価方法も検討すべきと考える。

\section{（3）資金需給ギャップを解消する方策について}

\section{a. 情報ギャップの解消について}

（i ）民間金融機関との情報ギャップを埋める 本稿の 4.（2）で見たとおり，「ヒアリング調 査」による実証分析では，病院と金融機関との間 にさまざまな情報ギャップが生じていると思われ る。またそれにも関わらず，これを解消する方策 を他業種に比して特別には整備していないため, 資金調達が円滑に行われていないと推察される。 情報ギャップを解消する方策としては，さまざま な環境整備と併せて，日本に抢ける病院向けの格 付機関や信用保証機関の創設が考えられる。

（ii）米国の病院資金調達の示唆

既に多様な資金調達手段を実現している米国の 事例加らられることは，病院の発行する債券の 信用リスクを補完する格付機関や保証専業保険会 社等の信用補完体制が整備されていることである。 これによって病院は, 自身の発行する債券の信用 リスク（金利等の条件）について，適正な評価を 


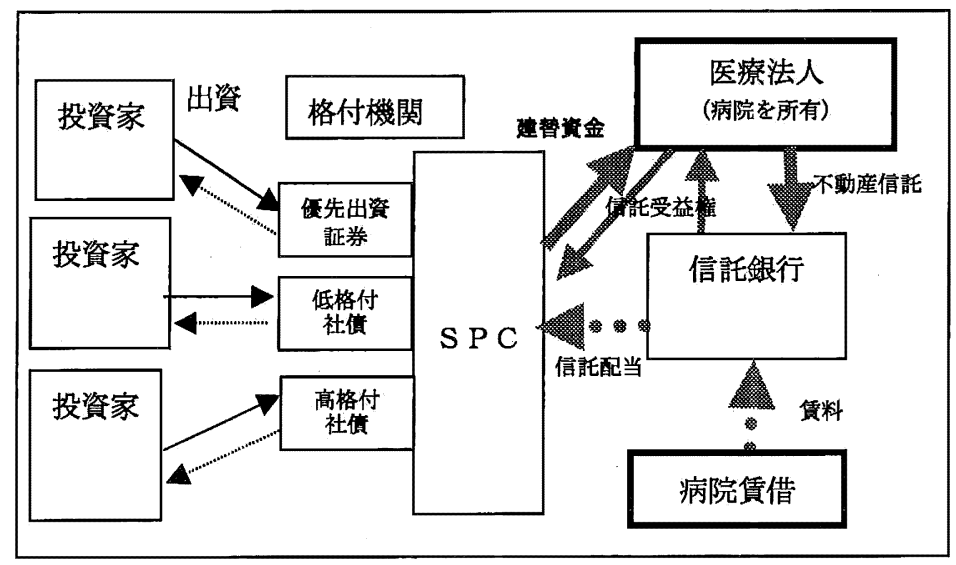

図 2 不動産証券化スキーム

得るとともに，その投資案件の期待収益率との比 較により当該投資の妥当性を検討することができ る。わが国においても金融機関での審查に全てを 期待するのではなく，間接金融をべースとした信 用補完機能の拡充を, 検討すべきではないだろう 加。

但し，米国と日本の実状の違いには留意してお くべきである。米国では「直接金融市場の発達」, 「多様な投資家層の存在」,「病院の機能や制度に 拈ける日本との大きな違い」等の外部環境に加え, 格付機関については約 40 年の歴史があり，かつ信 用保証機関についても，保証専業保険会社が数多 く存在している。したがって米国の制度をそのま ま模做するのではなく，日本の現状を踏まえての 検討が必要である。

\section{b. 信用補完制度創設の提案}

\section{（i ）信用補完制度の公民の役割分担}

日本ではこれまで，市場や機能の発達が遅れて いる時には，政府による介入を望む場合が多いが， 信用補完制度の整備については筆者はその立場を とらない。理由は政府が介在した場合，(a)審査面 で生産効率性による格差をその判断結果（格付グ

\footnotetext{
${ }^{6)}$ U.S. news online (2000) http//www.usnews.com
}

レードや保証料率）に反映させることに馴染まな いこと（平等公正を旨とせざるを得ないため), (b)同様の理由から，価格での調整（ここでは格付 費用や保証料率を戦略的に設定すること）を行わ ない可能性が高いこと，(c)財政資金や信用供与の 面で必ず予算制約を受けること，の 3 点である。 例えば，公的機関が格付機関や信用保証機関を創 設（または新たに当該業務を追加）してあ，平等 を旨とするためほとんどの病院が適格水準（例え ばBBB）に指定されたり，その公表を行わない ことが予想される。したがって格付機関及び保証 機関の整備は民間組織を中心にして行うべきと考 える。

\section{(ii ) 格付機関}

(1)わが国格付機関の現状

信用保証機関については，私的病院等に対する 格付機関は存在しない。但し病院機能評価機構等 が，プロセス面での品質基準を満たした私的病院 等に対して認定を与えているがこれは一種の資格 であり，信用リスクを定量化したあのではない。 また，財務的な項目は審査項目に入っていない。

\footnotetext{
7) Health Statistics (1994) American Medical Association
} 


\section{表10 わが国の保証機関の現状}

\begin{tabular}{|c|c|c|}
\hline 世体 & 7) & 伤 \\
\hline I 国 & 貿易保険特別会計のみ 1 & 貿易取引 \\
\hline II 特殊法人 & 信用保証協会他 & 政策金融等 \\
\hline III 公益法人 & 不動産保証協会他 & 業界掁興資金等 \\
\hline IV 信用保証会社 & 銀行系・生保系他 & 貸出債権（住宅ローン）等 \\
\hline $\begin{array}{l}\mathrm{V} \quad \text { 信販会社 } \\
\end{array}$ & 日本信眅他 & 提携銀行ローン等 \\
\hline VI 損害保険会社 & 東京海上火災他 & 信用保険・保証保険等 \\
\hline
\end{tabular}

注 1）証対象は，ほとんどが提槜金融機関債権

注 2）出資者は，ほとんどが関係金蝺機関関連会社（親会社・提携金融機関による信用獲得）

出所）各種信用保険・信用保証制度の概要（2000 年 3 月）中小企業総合事業団

\section{(2)求められる機能}

一般的に格付を行う場合には, 以下の 3 つの機 能が必要であると考える。一つは「財務データベー ス」として過去のデー夕を蓄積して, 審査する私 的病院のデータをベンチマークと比較できるよう にすることである。二つ目は，定量的・定性的指 標の審査結果を数值化する「スコアリング」であ る。具体的には，各指標にウエイトづけを行い 100点満点で採点することなどが考えられる。三 つ目は，スコアリングの点数を，過去のデータか らモデルを通じて，デフォルト率に転換する「デ フォルト率の算定」である。もちろん当初から現 在のS\&Pのような形での出発は困難だが，例え ばデータベースを持った金融機関と提携し，まず スコアリングからはじめる等が現実的であろう。 本稿ではこれらが全て可能であるとの前提に立っ て議論を進める。

機能としては金融機関との間で情報ギャップの 大きい，医療の質，規制・業種動向，地域市場分 析の機能を有し, 財務データの透明性や信頼性を 担保することが必要である。

(3)担い手について

既存格付機関を担い手として利用すべきであろ うか。日本の格付機関には医療福祉分野のノウハ ウがないと思われる。ムーディーズのような米国 格付機関は，前述の環境や機能の違いから米国の 手法をそのまま転用できないと考える。他業種の 例であるが，一時期わが国金融機関に対する米国
格付機関の格付の適正さに対して，さまざまな議 論が起きたことがある。これは格付とは最終的に 評価者の方針を反映するため，米国格付機関の金 融機関のあり方に対する考え方が，日本の関係者 の考え方と必ずしも一致しなかったためである。 このような格付機関と私的病院の間で，格付に対 する疑念が生じないように，米国格付機関がわが 国私的病院の格付を行うとしても，日本の独自性 を踏まえた格付を行う機関を新設し競合させるこ とが望ましいと考える。

この時, 格付機関の担い手となるのは, 大学等 の学術研究機関・会計事務所・医業経営コンサル タント事務所等が候補として考えられる。格付機 関については，中立性を重視することから民間の 非営利機関が適している。

(4)信用保証機関との一体運営の必要性一格付への 信頼性

しかし，一方で格付機関を新設した場合には, 通常デフォルト率で検証される格付機関への信頼 がすぐには得られないという問題が起きる。この ため日本における格付機関創設の際には，その格 付手法について正しく理解し，その格付に連動し た保証を行う機関（または機能）を併せて（経営 主体は別にして）設立する必要がある。また，特 定の信用保証機関や金融機関と上記内容について 提携することも考えられる（このときには格付プ ロセスと信用保証機関や金融機関の審查手法との 親和性についても十分に考慮する必要がある)。 


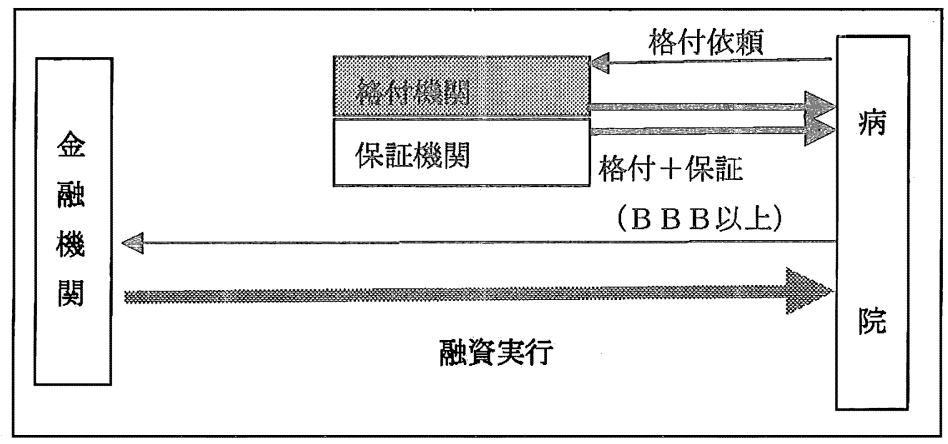

図 3 格付十保証スキーム

（ii）信用保証機関

(1)信用保証機関の現状

わが国においては，公的には全国の信用保証協 会（国，都道府県，民間金融機関が出資）が中小 企業向けに保証業務を行っており，医療業につい ても利用が可能である。しかし，私的病院向けの 保証審査ノウハウは蓄積されていないようである。 また，民間では専業の医療業向け信用保証会社は 有意には存在しないと考えられる（ほとんどが金 融機関の子会社であり，信用リスク測定ノウハウ を親会社に依存している場合が多い)。

(2)保証機関の機能

このため日本における格付機関創設の際には, その格付手法について正しく理解し，その格付に 連動した保証を行う機関（または機能）を併せて （経営主体は別にして）設立する必要がある。

(3)信用保証機関の担い手

民間で考えた場合最も現実的なのは，高格付を 取得している生命保険・損害保険会社の新規ビジ ネスとしての位置づけである。このような保証事 業は，高格付を維持することが肝要であり，一方 高格付を取得している会社にとっては，自らの信 用リスクの高さを利用しすることができるビジネ スである。日本においても，高格付を取得してい る生命保険・損害保険会社等の有力な新規事業と なりえると考える。 （iii）信用補完制度を利用した新しい資金調達ス キームの提案

(1)格付十保証スキーム

上記の格付機関と信用保証機関を組み合せれば, 現状の制度の下で，経斉合理性から私的病院を選 別し，長期安定資金を金融機関から調達すること が可能となる。図 3 は長期資金調達において, 一 定以上の格付を取得した者には，保証機関がセッ トで保証を行うというスキームである。銀行は保 証を裏付けに長期資金を融資することができる。

\section{6. 最後に}

私的病院による新たな資金調達には，規制面で の制約や情報公開等の課題が多い。ここに挙げた 資金調達スキームもそれぞれ既存ルールについて の検討や私的病院の資金需要に応じた微調整が必 要になろう。しかし，その実行に際しては全国一 律な導入実施を考えるのではなく，先進的な私的 病院による新たな資金調達スキームの先行実施を まず行い，その中で生じるさまざまな改良点から， 再度資金調達スキームを検討すべきであると考え る。また，格付機関についても最初から完全な審 查をめざすよりは，複数の格付機関が競争するこ とによって，格付を利用する病院や金融機関から 選別されていくことが必要と考える。 


\section{引用文献}

筧 淳夫（1996）「病院建築のライフスパン」『病院』 $55(8): 774-777$

濃沼信夫（2000）『医療のグローバルスタンダード』ミ クス

社会福祉医療事業団（2000）「病院診療所等の設備投資

の動向之事業団の関わり」『WAM』2000.03号

田中 滋 (1993)『医療政策とヘルスエコノミクス』日 本評論社

宮澤健一（2000）「公共投資加ら福祉医療へ」（日本経 済新聞，経済教室）

八代尚宏（2000）『社会的規制の経済分析』（日本経済 新聞社)

安川文朗（1997）「民間病院の資金調達について」『医 療之社会』 $7(3): 83-98$

\section{参考文献}

田中康雄（2000）「病院経営と設備投資のあり方」『病
院』59(3):212-215

第一生命研究所（1998）「設備投資の落ち込みが招いた 生産性の低下」

日本病院会 (1999)「病院概況調查報告書」

日本公私病院連盟 (1999)「病院経営分析調查報告」

TKCグループ (1999)「TKC経営指標」

建築物価調查会 (1999)「建築統計年報」

日本銀行（2000）「金融経済統計月報」(平成12年 5 月 号)

安田隆二, 大久保豊（1998）「信用リスク・マネジメン 卜革命」(金融財政事情研究会)

大垣尚司（1997）「ストラクチャードファイナンス入門」 (日本経済新聞社)

野間敏克，花枝英樹，米澤康博（1997）「企業金融」 （東洋経済新報社）

中小企業総合事業団 (2000)「各種信用保険・信用保証 制度の概要」

日経ヘルスケア編（1997）「病医院のための資金調達マ ニュアル」(日経BP社)

金融財政事情研究会（1999）「業種別貸出審查辞典」

（2000年 8 月 1 日受付，2000年10月 30 日採用） 


\title{
Problem with Financing Investments in Private Hospitals : Fund Demand Estimate and Recommendation of New Financing Method
}

\author{
Hiroyuki Kawaguchi*
}

\begin{abstract}
This paper discusses the investments of private hospitals, as they relate to the performance effectiveness of the Japanese health insurance reform. In response to the reformation, private hospitals need enough money to invest. Moreover, these hospitals should be selected by the capital market due to their economical efficiency.

Given the present circumstances, private hospitals have only one channel for bank loans when financing a long term investment. And private hospitals have less financing methods than other industries.

For supply-demand analysis, this paper roughly estimates the demand for investing in hospital re-construction, considering that the private hospital's useful life is 30 years and, after that, that all hospitals should re-construct. Result of the estimation is that there is a supply-demand gap for the investment which amounts to a maximum of 2,600 billion yen up to 1999 , double the average amount of hospital investment per year.

The principal cause of the demand gap is the information gap between private hospital and private financial institutions. That is caused by poor communication on both sides.

This paper suggests that to solve this problem of information gaps, one must establish a "rating agency" and "credit assurance institution that works closely with said rating agency" for private hospitals. Furthermore, it is important to adopt a new financing method that uses these credit insurance systems. This paper promotes the operation of these credit enhancing instruments by private sectors rather than by public sectors. Public sectors should pay attention to place equal footing with other industries in diversifing private hospital financing methods. Private sectors will try a variety of approaches to develop new financing methods for private hospital investments.
\end{abstract}

Keyword: Private hospital, Financing of investment, Information gap, Rating agency, Credit assurance institution

* International Research Iustitute of Health and Welfare 